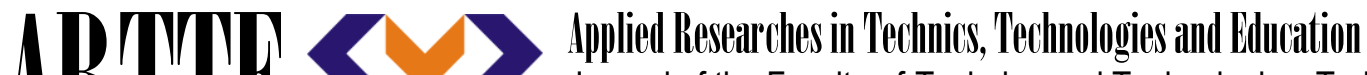 Journal of the Faculty of Technics and Technologies, Trakia University https://sites.google.com/a/trakia-uni.bg/artte/
}

\section{RESEARCH OF THE POSSIBILITY OF USING THE WIND POTENTIAL FOR GENERATION OF ELECTRICITY IN FACULTY OF TECHNICS AND TECHNOLOGIES OF YAMBOL}

\author{
Atanas Atanasov, Tanya Pehlivanova \\ Faculty of Technics and Technologies of Yambol, Trakia University, Bulgaria \\ Graf Ignatiev 38, 8600 Yambol, Bulgaria \\ e-mail: a.k.atanasov@trakia-uni.bg
}

\begin{abstract}
The article presents the results of wind potential research in the area of Faculty of Technics and Technologies of Yambol, Trakia University of Stara Zagora, Bulgaria. Measurements were made in the period from 01.06.2017 to 27.11.2017. For both seasons - summer and autumn the average wind speed and wind speed distribution are determined. The wind roses, which give a visual idea of the distribution of wind potential in different directions are build. Conclusions for the possibility of using the wind potential for extracting electricity are made.
\end{abstract}

Keywords: wind potential, wind speed, wind direction, wind energy project, power generation, urban areas.

\section{INTRODUCTION}

The use of renewable energy sources is a priority task in the field of energy. Through the last years the power generations technologies are greatly improved and new ones are being developed. Some of the most often built decentralized energy sources are wind generators $[1,2]$. The precise study of the wind characteristics and the meteorological peculiarities of the selected terrain is an important aspect of the preparation and operation of each wind energy project. On their basis an assessment is made and the optimal location and direction for installation of the wind turbines is determined $[3,4]$.

In urban areas, the choice of location of measuring equipment is important for objective results and for the future location of wind turbines. Measurements include wind speed and wind direction, on the basis of which its energy potential is determined. The choice of measuring instruments depends on the specific requirements and the regional, climatic and topographical conditions. Sensors for measuring wind speed, direction, atmospheric pressure, hydrothermal conditions, rainfall and solar radiation are most commonly used.

A key measurement parameter is the horizontal wind speed. For this purpose different types of anemometers are used, among the most preferred models are the cup anemometers and vane anemometers. The wind direction is determined by wind indicators. Measurements are essential for the optimal positioning of wind turbines.

This work presents the results of a wind potential survey in the region of Faculty of Technics and Technologies of Yambol, Trakia University of Stara Zagora, Bulgaria. The measurements were made with the PCE-FWS 20 meteorological station mounted on the roof of the building. The results are processed with Lakes Environmental WRPLOT View Freeware V.8.0.0 software with free access.

\section{METHODS}

The used meteorological station PCE-FWS 20, as installed in the Faculty of Technics and Technologies, shown in Figure 1, has the following options: Measurement of the wind speed: $0-180 \mathrm{~km} / \mathrm{h}$; Wind direction measurement: $0-360^{\circ}$. The wind speed can be measured in different units of measure $-\mathrm{km} / \mathrm{h}, \mathrm{mph}, \mathrm{m} / \mathrm{s}$, knots or bft.

IRTTE Vol. 6, No. 2, 2018 ISSN 1314-8788 (print), ISSN 1314-8796 (online), doi: 10.15547/artte.2018.02.011 


\section{ARTTIE \\ ( \\ Ipplied Reseirlches in Technicis, Technologies ind Bductition \\ Journal of the Faculty of Technics and Technologies, Trakia University https://sites.google.com/a/trakia-uni.bg/artte/}

The base station allows to store up to 4080 full-range records. This data is stored in a nonvolatile memory (EEPROM) and will not be lost even in the event of a power failure.

Reading, processing, display and change the data storage interval from 5 to 250 minutes. Connection of the Meteorological Station and a PC using a USB cable. Specialized software "EasyWeather", which allows data to be converted into different formats.

Weather data is sent wirelessly to a base receiver (receiving station) at a distance of up to 100 meters (space without obstacles). The receiving station is operated by a touchscreen. It has sensors to measure temperature, humidity and atmospheric pressure inside the room, has a USB interface for connecting to a computer.

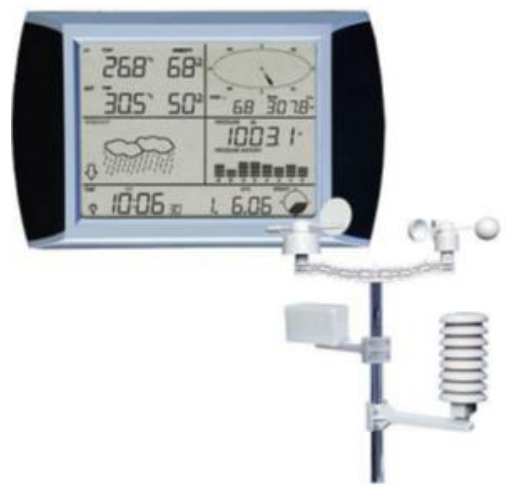

Figure 1. Meteorological station PCE-FWS 20

Data from the meteorological station is processed by the selected specialized software Lakes Environmental WRPLOT View Freeware V.8.0.0, which has the following capabilities:

Information on the location of the meteorological station that carried out measurements using geographic coordinates shall be entered, the number of wind directions and the number of speed intervals for which the calculations will be made, the unit of measurement in which the measurements are to be made. The orientation of the wind (the direction from which or to which the wind blows) for which the graphical results will be displayed shall be selected.

The start and end dates of the measurements, the place of storage and the format of the meteorological file, the interval through which the measurements are to be made shall be indicate.

After processing the input data, results are obtained in numerical, graphical and tabular form. Numerical results are displayed for average wind speed for the period, windlessness, frequency distribution of windlessness, available measurement information in percentages, number of incomplete / missing measurements, number of used measurements.

In graphical form are obtained:

The wind roses for different time periods (day, week, month, season, year or other). Wind rose is a graphical tool that gives a visual idea of how wind speed and direction are usually distributed in a particular area. In the polar coordinate system, color strips are drawn, the length of which depends on the wind frequency in a set range of wind speeds. The longest bands are in the direction in which the winds are at the highest frequency. The main wind direction is the second most important parameter when installing a wind turbine. It is especially important for power-powered wind turbines with small power that can not change their orientation.

The diagram also shows a resultant vector that combines the wind frequency in each direction to obtain a "middle" wind direction. Only the wind direction and number of measurements for each direction are used for calculation. The wind speed has no part in the calculation.

IRTTIE Vol. 6, No. 2, 2018 ISSN 1314-8788 (print), ISSN 1314-8796 (online), doi: 10.15547/artte.2018.02.011 


\section{ARTIIE \\ $(2$ \\ Ipplied Reseitrones in Technics, Technologies and Educration \\ Journal of the Faculty of Technics and Technologies, Trakia University https://sites.google.com/a/trakia-uni.bg/artte/}

The percentage of wind potential at different wind speed intervals. It allows to determine with very high accuracy for a specific wind turbine model, what amount of electrical energy would be obtained from the installed power (the power of the generator according to the technical documentation).

In tabular form are obtained:

Distribution of wind potential by speed. The number of measurements in each speed interval for each of the directions the meteorological station can account the results.

The distribution by direction, velocity interval and frequency of the measurements for calculating the average wind speed over the period. This is the most important indicator. From It calculates the energy potential of the particular area.

Information on the number of measurements for which there are no values as a percentage of all measurements.

Keeping the information in a Samson file format (.sam extension) used by most websites for meteorological information.

\section{RESULTS}

A wind rose and a resultant vector created for the Faculty of Technics and Technologies for the period from 15.06.2017 to 31.08.2017 (summer) is shown in Figure 2. It is chosen to draw the graph in the direction from which the wind blows. It can be seen that the winds that come from the south predominate - approximately $36 \%$. The resultant vector is in the direction of $192^{\circ}, 58 \%$ of the measurements.

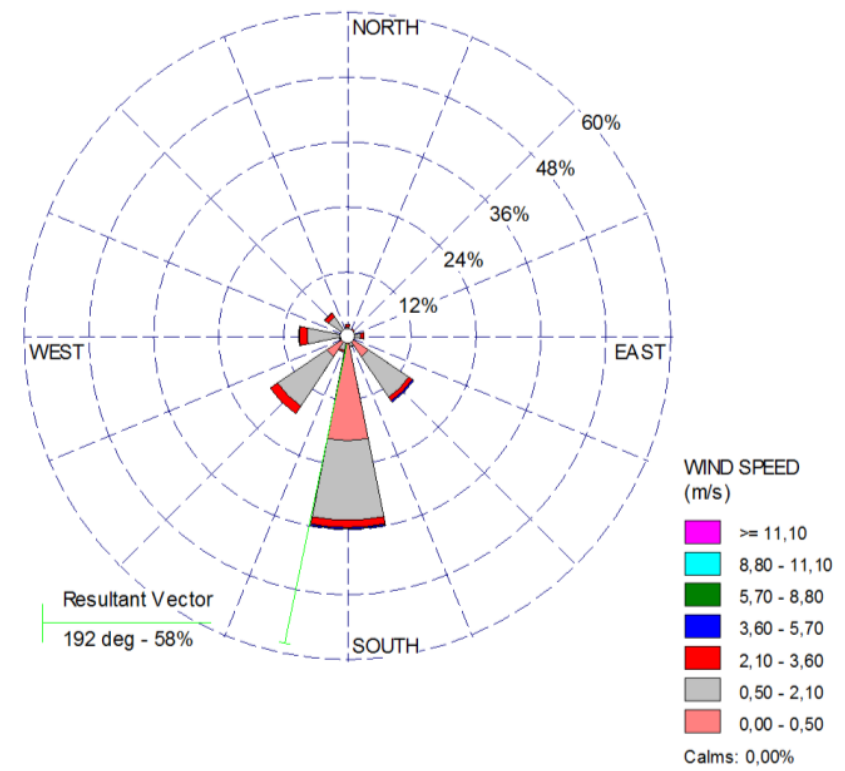

Figure 2. Wind rose and a resultant vector for the period from 15.06.2017 to 31.08.2017 (summer)

A wind rose and a resultant vector created for the Faculty of Technique and Technology for the period from 01.09.2017 to 27.11.2017 (autumn) is shown in Figure 3. The winds that come from the south predominate again but the percentage is smaller - about $20 \%$. This season, northeast winds are observed, which are missing in the summer. The resultant vector is in the direction of $201^{\circ}, 27 \%$ of the measurements.

IRTTIE Vol. 6, No. 2, 2018 ISSN 1314-8788 (print), ISSN 1314-8796 (online), doi: 10.15547/artte.2018.02.011 


\section{IRTITE}

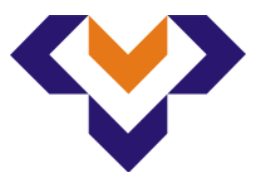

Ipplied Reseitrones in Technics, Technologies and Eductition

Journal of the Faculty of Technics and Technologies, Trakia University https://sites.google.com/a/trakia-uni.bg/artte/

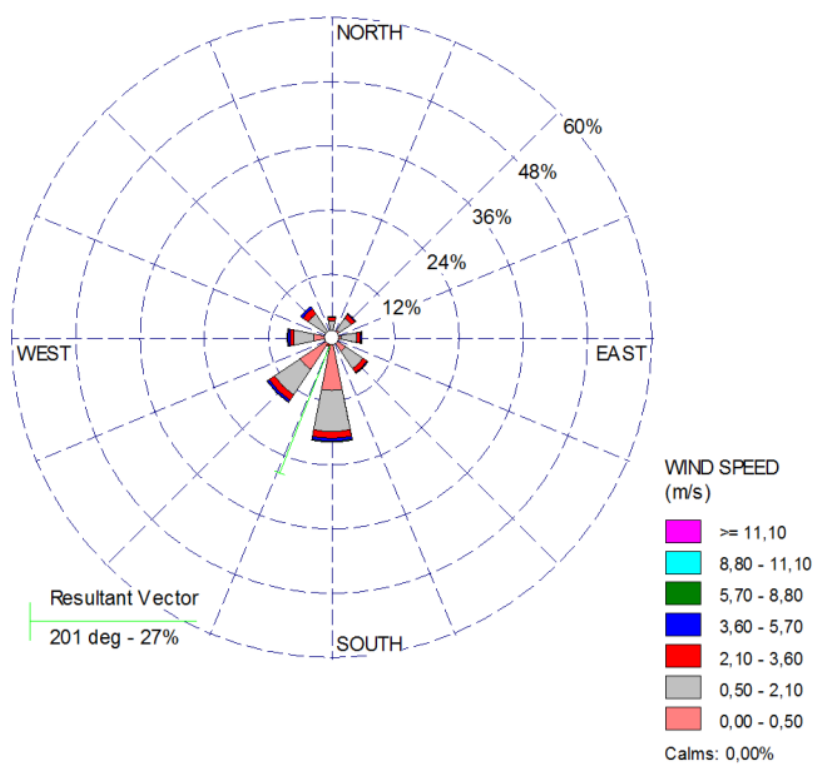

Figure 3. Wind rose and a resultant vector for the period from 01.09.2017 to 27.11.2017 (autumn)

The percentage ratio of wind potential at different wind speed intervals for the period from 15.06.2017 to 31.08.2017 (summer) is shown in Figure 4.

Figure 5 shows the percentage of wind potential for the same wind speed intervals for the period from 01.09.2017 to 27.11.2017 (autumn).

For the period from 15.06.2017 to 31.08 .2017 (summer), 1857 measurements were made, for 22.5 degree interval (16 directions of measurement). The average wind speed is $1 \mathrm{~m} / \mathrm{s}$.

For the period from 01.09.2017 to 27.11.2017 (autumn) 2081 measurements were made for a 22,5 degree interval (16 directions of measurement). The average wind speed is $1.08 \mathrm{~m} / \mathrm{s}$.

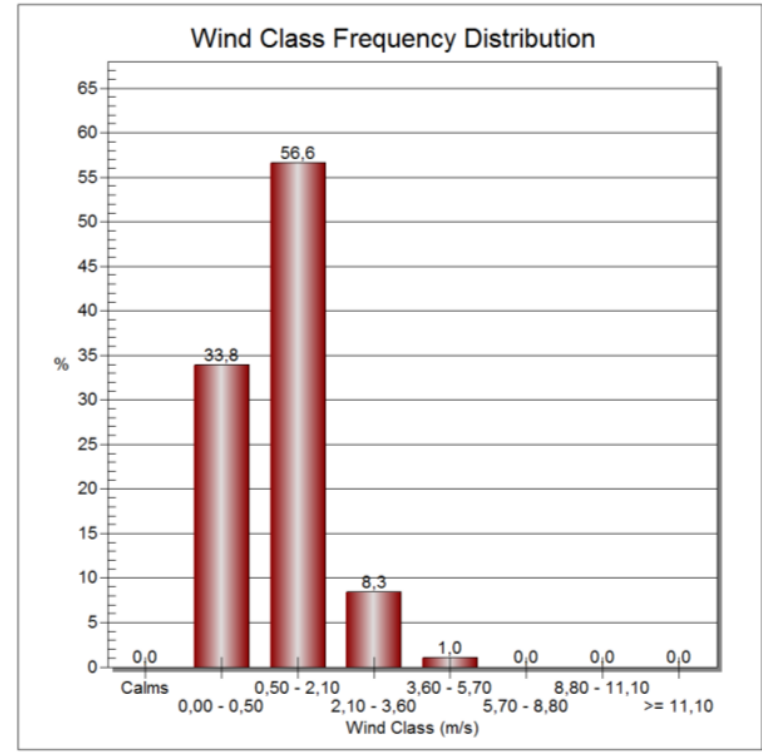

Figure 4. Percentage ratio of wind potential at different wind speed intervals for the period from 15.06 to 31.08 .2017 (summer)

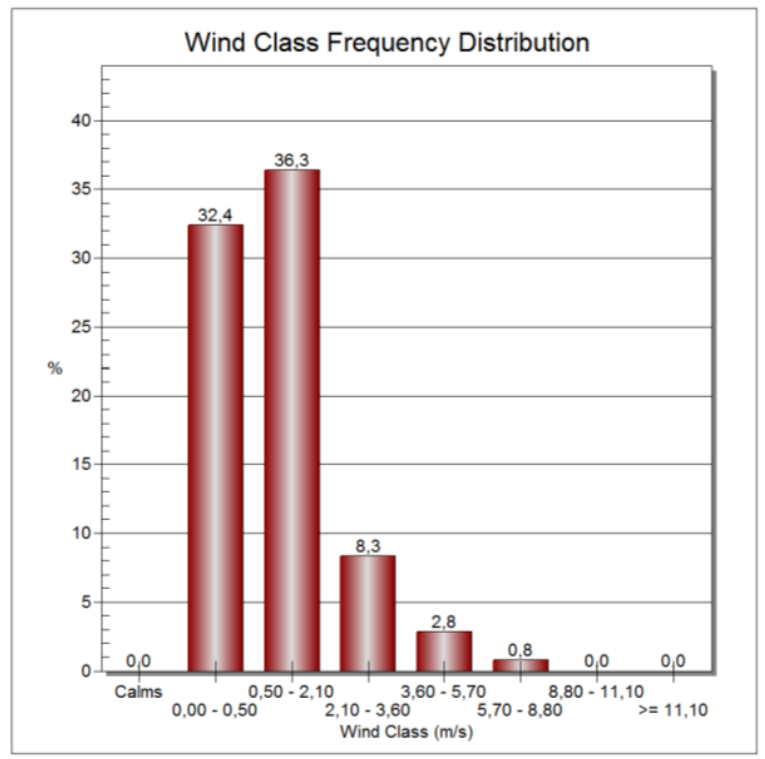

Figure 5. Percentage ratio of wind potential at different wind speed intervals for the period from 01.09.2017 to 27.11.2017 (autumn)

IRTIIE Vol. 6, No. 2, 2018 ISSN 1314-8788 (print), ISSN 1314-8796 (online), doi: 10.15547/artte.2018.02.011 


\section{IRTIIE}

Ipplied Researches in Technics, Technologies and Educiation

Journal of the Faculty of Technics and Technologies, Trakia University https://sites.google.com/a/trakia-uni.bg/artte/

Table 1 shows the results of wind potential measurements for each month and summed up for summer and autumn seasons over the entire surveyed period. The following data are presented:

- resultant vector for the prevailing wind direction and percentage of measurements in its direction (measurement time is through 1 hour);

- percentage of measurements at different wind speed intervals;

- average wind speed for each month separately;

- The total number of measurements per month. For months with 31 days, the total number of measurements is 744 , and 703 per month for 30 days. In the same column are the number, incomplete measurements (no data measured by the meteor station is missing).

Table 1. Summary of wind potential measurements

\begin{tabular}{|c|c|c|c|c|c|c|c|c|c|c|c|}
\hline \multirow{3}{*}{ Month } & \multirow{3}{*}{$\begin{array}{c}\text { Resultant } \\
\text { vector }\end{array}$} & \multicolumn{8}{|c|}{ Wind speed, $\mathrm{m} / \mathrm{s}$} & \multicolumn{2}{|c|}{$\begin{array}{c}\text { Number of } \\
\text { measurements }\end{array}$} \\
\hline & & \multicolumn{7}{|c|}{ in percent for each interval (\%) } & \multirow{2}{*}{$\begin{array}{c}\text { Average } \\
\text { speed for } \\
\text { the period } \\
\mathrm{m} / \mathrm{s}\end{array}$} & \multirow[b]{2}{*}{$\begin{array}{c}\text { total } \\
\text { number }\end{array}$} & \multirow[b]{2}{*}{ Incomplete } \\
\hline & & $0-0,5$ & $0,5-2,1$ & $2,1-3,6$ & $3,6-5,7$ & $5,7-8,8$ & $8,8-11,1$ & $\geq 11,1$ & & & \\
\hline June & $184^{0}-62 \%$ & $32 \%$ & $59,6 \%$ & $6,2 \%$ & $1,1 \%$ & & & & 0,99 & 369 & 4 \\
\hline July & $1950-52 \%$ & $33,2 \%$ & $56,9 \%$ & $9,3 \%$ & $0,5 \%$ & & & & 1,01 & 744 & 1 \\
\hline August & $1970-54 \%$ & $35,3 \%$ & $54,6 \%$ & $8,5 \%$ & $1,5 \%$ & & & & 1,00 & 744 & 1 \\
\hline September & $1960-31 \%$ & $29,3 \%$ & $51,6 \%$ & $13,7 \%$ & $4,3 \%$ & $0,4 \%$ & & & 1,27 & 703 & 3 \\
\hline October & $206^{0}-33 \%$ & $45,7 \%$ & $39,9 \%$ & $8,7 \%$ & $3,8 \%$ & $1,7 \%$ & & & 1,04 & 744 & 1 \\
\hline November & $2130-14 \%$ & $20 \%$ & $14,7 \%$ & $1,9 \%$ & $0,2 \%$ & & & & 0,67 & 634 & 401 \\
\hline Summer & $1920-58 \%$ & $33,8 \%$ & $56,6 \%$ & $8,3 \%$ & $1,0 \%$ & & & & 1,00 & 1857 & 4 \\
\hline Autumn & $2010-27 \%$ & $32,4 \%$ & $36,3 \%$ & $8,3 \%$ & $2,8 \%$ & $0,8 \%$ & & & 1,08 & 2081 & 403 \\
\hline
\end{tabular}

\section{CONCLUSIONS}

- It was found that for the summer (June - August), the prevailing percentage of winds are south-southwest. The speed is in the range of $0.5-2.1 \mathrm{~m} / \mathrm{s}$, which is insufficient to propel the available on the market slow-speed wind turbines.

- In October wind reorientation begins and its main direction is west-southwest. There is no significant increase of the speed in autumn (September to November).

- The results show that the standalone use of wind energy for generation of electricity the studied object is not possible. It is necessary to use the wind potential together with other renewable energy sources, i.e. the construction of hybrid power systems.

\section{REFERENCES}

[1] Nedelcheva S. (2013). Green Energy. Ed. of TU - Sofia, Sofia, 2013.

[2] Notov P., Nedelcheva S. (2016). Electrical power engineering, Volume 3, Intelligent Electrical Networks. Ed. of TU - Sofia, Sofia, 2016.

[3] Nedelcheva S, \& Lazarov I. (2015). Deciding to build wind power plants under conditions of uncertainty. Notifications of TU - Sliven, No. 6, 2015, 17-20.

[4] Nedelcheva S, \& Lazarov I. (2015). Trends in the use of renewable energy sources. Notifications of TU - Sliven, No. 6, 2015, 32-34.

IRTIIE Vol. 6, No. 2, 2018 ISSN 1314-8788 (print), ISSN 1314-8796 (online), doi: 10.15547/artte.2018.02.011 